\title{
NOTE
}

\section{Coqui frogs persist with the deadly chytrid fungus despite a lack of defensive antimicrobial peptides}

\author{
Louise A. Rollins-Smith ${ }^{1,2,3}$, Laura K. Reinert ${ }^{1}$, Patricia A. Burrowes ${ }^{4, *}$ \\ ${ }^{1}$ Department of Pathology, Microbiology and Immunology, Vanderbilt University School of Medicine, Nashville, TN 37232, USA \\ ${ }^{2}$ Department of Pediatrics, Vanderbilt University School of Medicine, Nashville, TN 37232, USA \\ ${ }^{3}$ Department of Biological Sciences, Vanderbilt University, Nashville, TN 37235, USA \\ ${ }^{4}$ Department of Biology, University of Puerto Rico, PO Box 23360, San Juan, Puerto Rico 00931, USA
}

\begin{abstract}
The amphibian skin fungus Batrachochytrium dendrobatidis $(B d)$ occurs widely in Puerto Rico and is thought to be responsible for the apparent extinction of 3 species of endemic frogs in the genus Eleutherodactylus, known as coquis. To examine immune defenses which may protect surviving species, we induced secretion of skin peptides from adult common coqui frogs E. coqui collected from upland forests at El Yunque. By matrix-assisted laser desorption/ionization time-of-flight (MALDI-TOF) mass spectrometry, we were unable to detect peptide signals suggestive of antimicrobial peptides, and enriched peptides showed no capacity to inhibit growth of $B d$. Thus, it appears that E. coqui depend on other skin defenses to survive in the presence of this deadly fungus.
\end{abstract}

KEY WORDS: Amphibians - Antimicrobial skin peptides · Batrachochytrium dendrobatidis . Eleutherodactylus coqui $\cdot$ Puerto Rico

The amphibian chytrid fungus Batrachochytrium dendrobatidis $(B d)$ causes the disease chytridiomycosis and poses a continuing threat to many tropical amphibians (Hoffmann et al. 2010). In Puerto Rico, it has led to the apparent extinction of 3 species, Eleutherodactylus karlschmidti (last seen in 1976), E. jasperi (1981), and E. eneidae (1990), and recent declines of 6 other species (Joglar \& Burrowes 1996, Burrowes et al. 2004). Previous studies have documented a strong positive correlation between the effectiveness of antimicrobial skin peptides and resistance to $B d$ in wild amphibians and in experimental infection studies (Woodhams et al. 2006a,b, 2007).

To investigate the mechanisms of resistance among surviving high-elevation frogs, we induced (via injection of norepinephrine bitartrate, $40 \mathrm{nmol} \mathrm{g}{ }^{-1}$ body weight) skin secretions from 15 adult males and
9 adult females of the common coqui E. coqui collected from El Yunque, Puerto Rico, in March 2014. At the time of collection, the frogs were swabbed for the presence of $B d$ by standard methods (Longo et al. $2013)$, and $8 / 24$ (33\%) were positive by $\mathrm{PCR}$, with a mean infection intensity of 618.5 (range: 1-4888) $B d$ zoospore genomic equivalents. The skin secretions were enriched for hydrophobic peptides by passage over C-18 Sep-Paks (Waters) and examined by matrix-assisted laser desorption/ionization time-offlight (MALDI-TOF) mass spectrometry as previously described (Rollins-Smith et al. 2006, Woodhams et al. 2006b).

Two mass signals (mass to charge, $\mathrm{m} / \mathrm{z}$ ) at 1225 and 1436 were observed in 8 and 6 samples, respectively, and were present equally in both males and females (Fig. 1). However, other mass signals in the range of antimicrobial peptides were not detected. When 


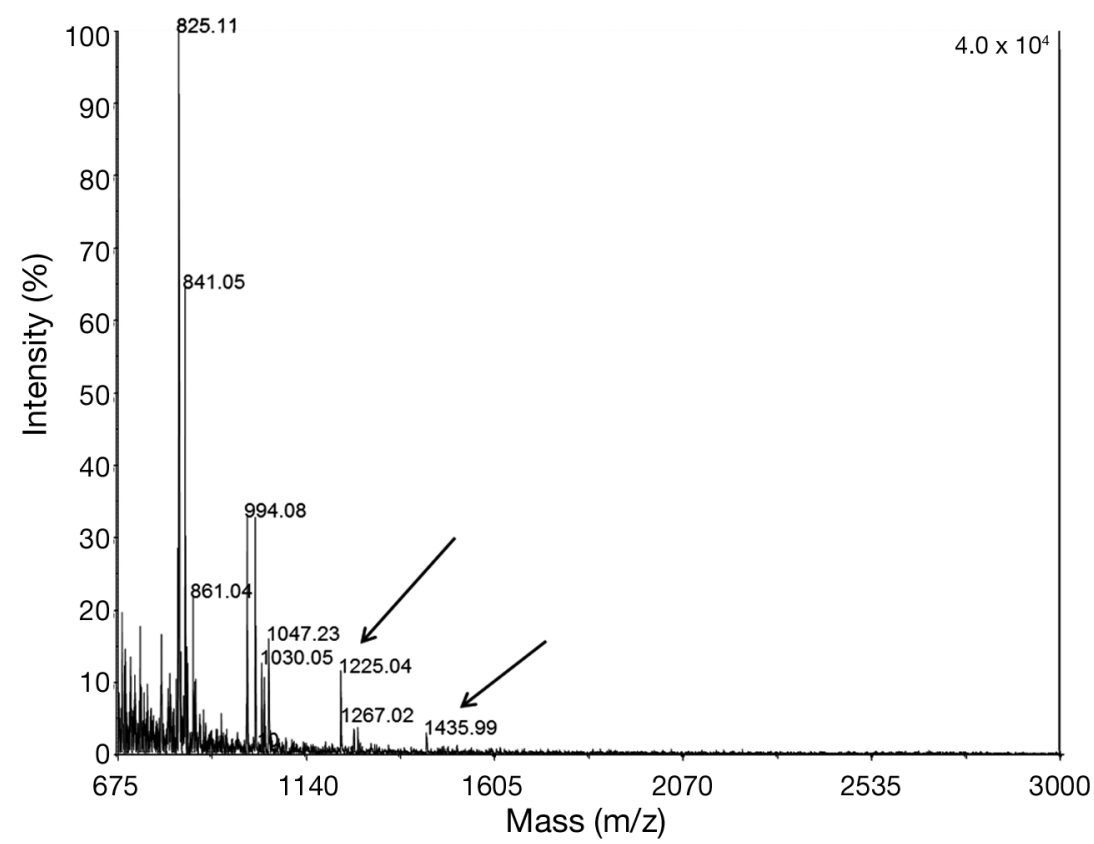

Fig. 1. Representative matrixassisted laser desorption/ionization time-of-flight profile of peptides recovered from an adult male Eleutherodactylus coqui after injection of $40 \mathrm{nmol}$ norepinephrine $\mathrm{g}^{-1}$ body weight. Arrows indicate mass signals (mass to charge, $\mathrm{m} / \mathrm{z}$ ) at 1225 and 1436 which were present in multiple individuals

enriched mixtures of the skin peptides were tested for their capacity to inhibit growth of $B d$ zoospores (Rollins-Smith et al. 2006), the peptides showed no inhibition of growth at concentrations as high as $200 \mu \mathrm{g} \mathrm{ml}^{-1}$ (Fig. 2).

The complex interactions of $B d$ with $E$. coqui are the subject of ongoing investigations. Cool temperatures and dry conditions appear to promote disease

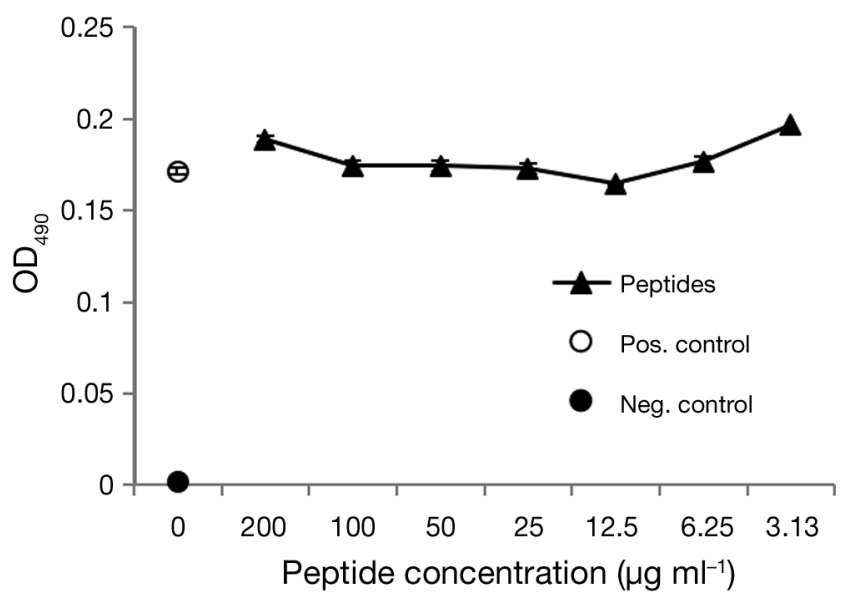

Fig. 2. Representative assay of growth inhibition of $B d$ zoospores (isolate JEL197) by peptides from a male Eleutherodactylus coqui. Note that even at the highest concentration of peptides, there was no inhibition of growth. This assay was repeated for peptide samples from 4 individual frogs ( 3 males and 1 female). $\mathrm{OD}_{490}$ : optical density at $490 \mathrm{~nm}$. Error bars are mean \pm SE of 5 replicates of zoospores with or without added peptides. The positive control was zoospores alone with broth. The negative control was heat-killed $\left(60^{\circ} \mathrm{C}\right.$ for $10 \mathrm{~min}$ ) zoospores with broth development, while warmer temperatures at other times of the year promote survival (Longo et al. 2010). In spite of an average $B d$ prevalence of $43 \%$ among highland populations, E. coqui survive with low to moderate infection intensities averaging 1003 $B d$ zoospore genomic equivalents, a pattern indicative of enzootic conditions (Longo \& Burrowes 2010). However, the fact that these frogs die from chytridiomycosis when environmental conditions are harsh both in the lab and in the wild suggests that they are susceptible to $B d$ (Longo et al. 2010, 2013), and that a mechanism to resist high infections is effective during favorable times. Thus, E. coqui is an excellent model to study the evolution of defense and how environmental factors may modulate the processes involved. Given that antimicrobial peptide defenses appear to be lacking in this species, other skin defenses such as production of lysozyme, mucosal antibodies, or protective skin bacteria (Rollins-Smith et al. 2011) may play a greater role in protection. These studies are underway, and we hope that they may reveal alternative defense mechanisms that provide resistance or tolerance to this pathogen in changing environments.

Acknowledgements. This research was supported by National Science Foundation Grant IOS-1121758 (to L.A.R.S.). We thank Dr. Rafael Joglar, Louis A. Santiago, Andrés Rodriguéz Goméz, and Michel Alejandro for assistance in collection and sampling of the frogs. We thank Dr. Alberto Sabat and the students of the Topics in Molecular Biology course at the University of Puerto Rico at Río Piedras for assistance with the collection of skin peptides. 


\section{LITERATURE CITED}

Burrowes PA, Joglar RL, Green DE (2004) Potential causes for amphibian declines in Puerto Rico. Herpetologica 60: 141-154

Hoffmann M, Hilton-Taylor C, Angulo A, Böhm M and others (2010) The impact of conservation on the status of the world's vertebrates. Science 330:1503-1509

Joglar R, Burrowes P (1996) Declining amphibian populations in Puerto Rico. In: Powell R, Henderson RW (eds) Contributions to West Indian herpetology: a tribute to Albert Schwartz. Contributions to herpetology, Vol 12. Society for the Study of Amphibians and Reptiles, Ithaca, NY, p 371-380

Longo AV, Burrowes PA (2010) Persistence with chytridiomycosis does not assure survival of direct-developing frogs. EcoHealth 7:185-195

Longo AV, Burrowes PA, Joglar RL (2010) Seasonality of Batrachochytrium dendrobatidis infection in directdeveloping frogs suggests a mechanism for persistence. Dis Aquat Org 92:253-260

Longo AV, Ossiboff RJ, Zamudio KR, Burrowes PA (2013) Lability in host defenses: terrestrial frogs die from

Editorial responsibility: Alex Hyatt,

Geelong, Victoria, Australia chytridiomycosis under enzootic conditions. J Wildl Dis 49:197-199

Rollins-Smith LA, Woodhams DC, Reinert LK, Vredenburg VT, Briggs CJ, Nielsen PF, Conlon JM (2006) Antimicrobial peptide defenses of the mountain yellow-legged frog (Rana muscosa). Dev Comp Immunol 30:831-842

Rollins-Smith LA, Ramsey JP, Pask JD, Reinert LK, Woodhams DC (2011) Amphibian immune defenses against chytridiomycosis: impacts of changing environments. Integr Comp Biol 51:552-562

Woodhams DC, Rollins-Smith LA, Carey C, Reinert LK, Tyler MJ, Alford RA (2006a) Population trends associated with antimicrobial peptide defenses against chytridiomycosis in Australian frogs. Oecologia 146:531-540

> Woodhams DC, Voyles J, Lips KR, Carey C, Rollins-Smith LA (2006b) Predicted disease susceptibility in a Panamanian amphibian assemblage based on skin peptide defenses. J Wildl Dis 42:207-218

Woodhams DC, Ardipradja K, Alford RA, Marantelli G, Reinert LK, Rollins-Smith LA (2007) Resistance to chytridiomycosis varies by amphibian species and is correlated with skin peptide defenses. Anim Conserv 10: 409-417

Submitted: September 8, 2014; Accepted: November 11, 2014 Proofs received from author(s): January 5, 2015 